\title{
O Gênero Deliberativo na Oratória Grega: A Terceira Filípica de Demóstenes e a Retórica de Aristóteles
}

Isis Borges B. da Fonseca

Universidade de São Paulo

FONSECA, I. B. B. O gênero deliberativo na oratória grega. Classica 3:60-67, 1990 .

ABSTRACT: L'ingéniosité dans le dévéloppement de l'art de parler chez les Grecs peut être appréciée dès le début de leur littérature. Néanmoins, ce n'est qu'au V' siécle av. J.-C. qu'apparaît une théorie de cet art, en Sicile, rattachée alors à la Grèce comercialement et politiquement. Au IV siècle av. J.-C., à Athènes, Aristote, dans sa Rhétorique, définit clairement les normes de la critique des discours. Il faut donc se fonder sur Aristote pour étudier ce modèle du genre délibératif qu'est la Troisième Philippique de Démosthène, où ressort l'habilité de l'orateur dans la combinaison des types de pisteis.

Os gregos eram naturalmente eloqüentes e desenvolveram ao longo da história uma arte de falar, cujas fases podemos seguir de Homero aos grandes discursos do século IV a. C.

Como ocorreu com a literatura grega em geral, as manifestações da eloqüência, quando já traziam consigo uma longa tradição, assumiram gradualmente a forma escrita. Assim, nos poemas homéricos, que representam o ponto alto de uma tradição oral de poesia épica, encontram-se ora discursos inteiros pronunciados em assembléias ou diante de pequenos grupos de homens, ora tentativas evidentes de persuasão (Kennedy, $1963: 6$ ) .

Além dos poemas épicos, também os elegíacos e líricos apresentam discursos com o objetivo claro de convencer. $\hat{\mathrm{E}}$ o que se observa nos fragmentos de Calino, ${ }^{1}$ quando ele exorta os compa-

${ }^{1}$ Calino de teseso, do século VII a. C., nos fragmentos de poesia elegíaca existentes, mostra-se influenciado por Homero, em seu estilo. 
triotas a agir em defesa da Pátria ameaçada, e na Ode a Afrodite, em que Safo ${ }^{2}$ implora a proteção da Deusa contra as penas do coração. Em ambos os casos, os poetas esperam ser atendidos em seu apelo, por sua força de persuasão.

Importante fonte para o estudo da eloqüência se tem também nas tragédias que oferecem situações que lembram cenas de tribunais. Veja-se, por exemplo, entre outros, o julgamento de Helena em Troianas (911 et seqs). Ela defende sua causa apoiada no argumento da vítima inocente que Afrodite sacrificou a Páris para que este lhe desse a vitória no concurso das deusas.

As obras históricas do século $\mathrm{V}$ registram grande número de discursos. Quando Heródoto os insere na narração, eles apresentam argumentos de certa extensão e importância. Mas é sobretudo Tucidides que, em função de seu método histórico, reconstitui os discursos efetivamente pronunciados nas assembléias, baseado na memória dos homens e num cálculo de probabilidades, efetuado a partir da sua análise dos fatos.

Ainda no século $\mathrm{V}$ os que falavam nas assembléias não publicavam os discursos. ${ }^{3}$

O valor da eloqüência acentuou-se quando, com a substituição da tirania pela democracia, o cidadão, tomando consciência da liberdade de ação que o novo regime lhe assegurava, passou a reivindicar abertamente os seus direitos diante dos tribunais. Com a queda da tirania da Sicília, tão grande número de litígios surgiu que levou Córax e Tísias a pensar em ensinar a técnica da retórica judiciária. Sua arte retórica é datada do século V a. C. Não muito depois de preparada, essa obra deve ter passado a Atenas, que, naquela época, mantinha fortes relações comerciais e políticas com a Sicília.

Diz Navarre (1900:23) que as contestações diárias entre comerciantes de Siracusa e Atenas, apresentadas ora numa, ora

\footnotetext{
Safo de Lesbos compôs hinos, epitalâmios e poesias eróticas. No poema cítado, assim se dirige à Deusa: «Vem a mim também agora, liberta-me de terríveis / cuidados, tudo quanto meu coração deseja, concede [...]» (25-7) . 3

Diz Platão (Phaedr. $257 \mathrm{~d} 5$ ) que eles tinham receio de ser tachados de sofistas.
} 
noutra localidade, devem ter contribuído muito para divulgar, na última, a teoria da eloquiência da autoria de Córax e do seu discípulo Tísias.

Paralelamente aos julgamentos, produziam-se os debates políticos diante da Assembléia popular, a ekklesia. ${ }^{4}$ Os intereeses da pólis e as discussões dos partidos constituíam, desde o início, a base da eloqüência deliberativa.

Quanto ao estudo específico dos discursos políticos, realizou-se nas escolas dos sofistas, alguns dos quais ensinavam a seus discípulos modelos de discursos e lugares-comuns adaptáveis a uma grande variedade de ocasiões políticas. O orador era preparado para aconselhar ou desaconselhar os membros da Assembléia popular a tomar certas decisões e medidas.

A teoria da retórica deliberativa não recebeu expressão formal até o tempo de Aristóteles e Anaxímenes; mas, pelos fins do século V e princípios do IV, a julgar pelos discursos dos historiadores e por alguns outros exemplos, a oratória deliberativa era influenciada pelas regras dos discursos judiciários (Kennedy, $1963: 203-4$ ) . De acordo com elas, verifica-se que o discurso deliberativo apresenta um proêmio, por vezes uma narração, argumentos de probabilidade, exemplos históricos e tópicos (como, por exemplo, os da utilidade, do justo, do honesto) e, por fim, o epílogo.

$\mathrm{Na}$ primeira metade do século. IV a. C., alguns oradores devem ter publicado discursos deliberativos, anteriormente pronunciados, mas infelizmente se perderam. Demóstenes foi o primeiro a publicar discursos redigidos.

A tradição manuscrita legou-nos uma coleção de onze discursos deliberativos de Demóstenes de autenticidade não duvidosa, e este conjunto fornece-nos uma preciosa informação sobre os fatos mais significativos da vida política ateniense no período de 354 a 341 .

\footnotetext{
4

$\mathrm{Na}$ época clássica, as assembléias regulares de pleno direito (kyriai ekkesiai) eram convocadas quatro vezes por pritania, isto é, quarenta vezes por ano. Quando a matéria em pauta não tinha solução numa assembléia, constituía-se outra, dita assembléia extraordinária (synkletos ekklesia). As ekkklesíai tinham poder soberano. Além de legislar, ocupavam-se das eleições, da fiscalização dos-magistrados, da política estrangeira, encarregando-se ainda do exílio, confiscação e condenação à morte. Cf. Lavedan, $1931: 120$.
} 
A Terceira Filípica, datada de 341 , destaca-se nesse conjunto como a peça oratória de elaboração mais perfeita. Nela o orador não se dirige apenas aos seus concidadãos, mas a todos os helenos que desejavam conservar a liberdade. Assim, a luta contra o rei Filipe da Macedônia adquire aqui uma universalidade que jamais teve. Demóstenes procura alertar os diversos pontos do mundo grego ameaçados e uni-los num ataque organizado ao inimigo. O momento parecia-lhe decisivo, e a situação, de risco geral para todos e de suma gravidade, não comportava realmente quaisquer hesitações ou delongas. Já desde o proêmio se percebe o tom de decisão extrema decorrente dessa universalidade característica do discurso.

$O$ orador, que no plano interno se voltara sempre para 0 interesse da sua Cidade e, na política externa, para o princípio do equilíbrio do poder, sentiu então que a questão da liberdade dos gregos estava acima da hegemonia de Atenas. $\mathbf{E}$ empregou toda a capacidade de persuasão, todo o ardor patriótico em defesa "da salvação da Grécia, que já estava com o adversário aquém das suas fronteiras. Desde as Guerras Médicas, ela nunca estivera tão gravemente ameaçada por inimigo externo como estava agora; o perigo e o adversário comum forçosamente provocariam a união desejada.

Diante da gravidade da situação e da urgência de uma tarefa que sempre propusera, de salvação nacional, a emoção do grande orador extravasa no mais belo de seus discursos, harmoniosamente articulado com um senso de composição e uma força de argumentos já demonstrados anteriormente, mas aqui enriquecidos por uma aguda sensibilidade à iminência do perigo.

Para um comentário sobre essa peça oratória, do ponto de vista retórico, não se pode díspensar um resumo que reavive o seu desenvolvimento. Nós nos deteremos, entretanto, somente no conteúdo do proêmio e do epílogo, deixando o do corpo do discurso, isto é, o conteúdo da argumentação, apenas para comentários elucidativos, dado o grande número de parágrafos dele constante (setenta) .

O proêmio, formalmente, compõe-se de cinco parágrafos:

Fala-se continuamente nas assembléias das ofensas de Filipe à Hélade. Todos concordạm em que é necessário pôr-lhe um fím. 
No entanto, a situação de Atenas é tão má que, mesmo se todos se propusessem arruiná-la, não estaria ela pior. Responsáveis por isso são os maus conselheiros que só querem ser agradáveis ao povo, uns por falta de previsão, outros pelo apoio que dão a Filipe. A liberdade de palavra, concedida a estrangeiros e até a escravos em Atenas, é negada ao orador na ekklesía. Se ele puder falar francamente, os erros ainda poderão ser corrigidos. Na realidade, Filipe venceu a indolência dos atenienses e não a pólis.

Resumido o proêmio, é de interesse iniciar a apreciação do discurso com base numa crítica retórica, cujas normas são bem definidas a partir de Aristóteles.

No discurso retórico, esse autor distingue três elementos que concorrem para o desempenho de sua função específica que é a persuasão. A esses elementos ele chama pisteis (provas) e os classifica em subjetivos e objetivos (Rhet. 1356 a). As provas subjetivas são o êthos e o páthos. As provas objetivas são fornecidas pelo silogismo retórico (enthymema) e pelo exemplo, que corresponde à indução dialética.

Esses três tipos de provas correspondem em princípio às três partes principais do discurso; o páthos aparece sobretudo no epílogo, enquanto o entimema e os exemplos se encontram na argumentação, que constitui o corpo do discurso. O êthos consiste no artifício do orador em criar a seu respeito, pelo seu enunciado, uma figura, um caráter, que predisponha os ouvintes à persuasão, e essa predisposição é em geral conseguida pela impressão de benevolência, que o ouvinte sente no orador. E para conseguir essa impressão de benevolência, este em geral evita desagradar o ouvinte e procura o contrário, isto é, agradá-lo.

No proêmio, podemos ver que os cinco parágrafos constituem o êthos através de uma argumentação que envolve os acontecimentos, a atitude dos oradores e a dos ouvintes numa trama de relações que ressalta a figura do orador benevolente, porque ele diz a verdade não à custa da lisonja, não porque ele diz o agradável, mas ao contrário: mesmo contra a lisonja, contra o agradável, a benevolência do orador transparece na denúncia dos fatos desagradáveis aos membros da assembléia. O orador evoca exemplos que confirmam o acerto das suas previsões e a coerência de sua 
posição. Isso lhe dá o prestígio e a força do bom conselheiro. E essa figura do orador competente, bem firmada no proêmio, continua no tom de sua argumentação e mesmo nas breves sentenças do epílogo.

Dentro da argumentação, encontramos o entimema e o exemplo, as chamadas provas objetivas, que constituem propriamente o núcleo, o momento decisivo da persuasão. O primeiro difere do silogismo por basear-se em princípios não necessários, mas em verossimilhanças ( tà eikóta), em sinais certos (tekméria) e sinais prováveis (semêia) (Arist. Rhet. $1357 \mathrm{a}-\mathrm{b}$ ). Aristóteles os considera como próprios sobretudo da oratória judiciária, mas eles são muito importantes nos discursos deliberativos de Demóstenes, tão importantes quanto os exemplos, considerados pelo filósofo como próprios do gênero deliberativo e presentes na Terceira Filípica em muitos momentos da argumentação.

Os princípios. não necessários do discurso retórico são classificados por Aristóteles em tópoi e eide (Rhet. 1358 a); os primeiros são gerais e por isso também chamados koinoi tópoi, enquanto os segundos são as premissas próprias de cada um dos três gêneros da eloqüência. Os tópicos mais importantes do gênero deliberativo são: rendas, guerra e paz, proteção do território, importação e exportação, e legislação.

Os koinoi tópoi dizem respeito ao possível ou ao impossível, ou demonstram que algo acontecerá ou não, ou, ainda, tratam da grandeza.

Na Terceira Filípica, a argumentação desenvolve de maneira muito vigorosa um dos tópicos específicos apontados por Aristóteles: o da guerra e da paz. Este é o núcleo do discurso. A sua importância aqui está ligada à necessidade de deixar bem caracterizada uma questão de fato - o estado de guerra - em conflito com uma situação legal - a da paz oficial.

Para tratar desse problema central, além de servir-se de outros tópicos específicos, Demóstenes utiliza sobretudo, com grande habilidade, os koinoi tópoi. Com os exemplos dos ataques aos habitantes de Olinto, Fócida, Feras ( $\$ 11-2)$, o orador mostra a uniformidade da conduta do rei macedônico diante das suas vítimas, que só tardiamente têm consciência da sua triste situação. Tudo indica 
que Atenas terá o mesmo fim, se não puser um termo às ofensas de Filipe. Se ele alcançou os seus objetivos nos outros casos, agindo com astúcia, e não como inimigo declarado, é provável que o mesmo se dê com Atenas, se não mudar de atitude.

Insiste o orador ainda no maior ou menor grau de facilidade na ocorrência do fato, quando compara a atitude passiva de Atenas com a de outras cidades já dominadas ( $§ 354$ ). O tom de censura está claro nessa observação. Ainda frisa que, se não corrigirem os seus erros, os helenos serão vencidos, pois, se tantas cidades caíram nas mãos de Filipe, é possível que também o mundo grego todo tenha esse fim.

Não menos considerável é o lugar que se baseia no fato que se produzirá ou não no futuro. Se uma ação que visa a um certo fato se produziu, é provável que esse fato se produza (Arist. Rhet. 1359 a). Assim, todos os atos praticados por Filipe contra Atenas são prenúncios da investida final à Ātica que, submetida, dará à Macedônia o domínio sobre a Hélade.

Quanto ao tópico da grandeza, que compreende a amplificação (aúxesis) e a atenuação (meiosis), ${ }^{5}$ dele se serve Demóstenes também com muita felicidade. $O$ orador qualifica Filipe através de um confronto com os helenos, pelo qual, à medida que estes são engrandecidos, o primeiro é diminuído. Assim é amplificada a inferioridade de Filipe. Por esse processo o orador procura despertar nos ouvintes sentimentos de brio, de orgulho, de honra, que poderão animá-los a sair da inércia costumeira.

E ainda um exemplo de meíosis a atenuação das faltas cometidas pelos lacedemônios e atenienses, nas suas fases de hegemonia, e confrontadas com as de Filipe. Exemplo de fatos históricos apóiam as assertivas do orador. $\hat{\mathbf{E}}$ evidente que com a atenuação dos erros dos helenos, há o agravamento (aúxesis) dos de Filipe.

Além desses tópicos, definidos por Aristóteles como propriamente técnicos, aparecem outros na Terceira Filipica, que a crítica retórica posterior, chamando-os também lugares-comuns, distingue

5

Arist. Rhet. 1391 b 30; Lausberg, 1966: T. I \& 260. 
todavia dos que Aristóteles considera técnicos. Exemplo deles é o elogio dos antepassados e a apresentação de Atenas como protetora da justiça e defensora da liberdade da Hélade. Estes tópicos foram de fato muito repisados na retórica do século IV. Entretanto, o critério para diferençá-los daqueles que são técnicos parece ser apenas o fato de eles serem repetidos inconscientemente e, portanto, mal usados. Nesse caso, a Terceira Filípica não apresenta tais tópicos, pois o elogio dos antepassados ( $\$ 14$ ) e a grandeza moral de Atenas ( $\S 73$ ) estão aqui, como, aliás, em outros discursos, cuidadosamente associados aos elementos de argumentação do possível e impossível.

$\mathrm{Na}$ Terceira Filípica, o epílogo se resume num único parágrafo. Nele o orador reafirma que tudo pode ser corrigido se forem adotadas as medidas propostas, mas a sua convicção admite que outros possam dar melhor conselho e, ainda, formula finalmente um voto aos Deuses, para que a decisão final dos atenienses seja em seu próprio proveito $(\S 76)$.

A prova considerada própria do epílogo é o páthos, ${ }^{6}$ artifício que consiste em predispor à persuasão através de sentimentos (como piedade, indignação, esperança) despertados a respeito de pessoas, fatos ou acontecimentos de que o orador fala. O páthos é complementar ao êthos e com ele está naturalmente vinculado.

O epílogo da Terceira Filípica é sóbrio e também não é nele que se situa exclusivamente o páthos. Este, mais ainda que o êthos, se encontra no discurso todo. Já desde o exórdio ele aparece, por exemplo, na hipótese imaginada pelo orador no $\S 1$, de que todos os oradores falassem em vista de criar uma situação péssima. Ele está também em muitos pontos da argumentação que tendem a exacerbar os sentimentos de indignação, ironia, honra, vergonha. Está ainda em vários exemplos, explorado com muita habilidade.

Por todos os comentários feitos, conclui-se que a Terceira Filípica, atravessando os séculos, constitui ainda hoje um dos grandes exemplos de retórica autêntica.

Arist. Rhet. 1356 a 14-8; Pol. 1419 b 25. 


\section{BIBLIOGRAFTA}

I. OBRAS DE REFERÊNCIA

LIDDEL, H. C. \& SCOTT, R. Móskhow \& Konstantinídou. Méga Lexicòn tês Hellenikês Glósses. Athênai, I. Sidéres, 1977.

LAVEDAN, P. Dictionnaire illustré de la mythologie et des antiquités grecques et romaines. Paris, Hachette, 1931.

\section{Obras Gerais e Especiais}

KENNEDY, G. The Art of Persuasion in Greece. London, Routledge \& Kegan, 1963.

LAUSBERG, H. Manual de retórica literaria. Madrid, Gredos, 1966.

NAVARRE, O. Essai sur la rhétorique grecque avant Aristote. Paris, Hachette, 1900 .

\section{TeXtos}

ARISTOTE. Rhétorique. Paris, «Les Belles Lettres», 1967.

DEMOSTHENE. Harangues. Paris, «Les Belles Lettres», 1967.

PLATON. Phedre. Paris, «Les Belles Lettres», 1966:

TOVAR, A. ARISTóteless. Retórica. Madrid, Instituto de Estudios Políticos, 1971 .

Conferência proferida durante a $3^{\circ}$ Reunião Anual da SBEC, no Rio de Janeiro, em 26/07/1988.

Aceita para publicação em $03 / 11 / 1989$ 